Uzun, Y. ve Sünter, M. (2020). Tartışmacı metin yazmanın öğrencilerin yazma becerilerine, eleştirel düşünmelerine, yazmaya yönelik tutumlarına ve kalıcılığa etkisi. Ana Dili Eğitimi Dergisi, 8(1), 157-169.

Ana Dili Eğitimi Dergisi
Journal of Mother Tongue Education
www.anadiliegitimi.com

\title{
Tartışmacı Metin Yazmanın Öğrencilerin Yazma Becerilerine, Eleştirel Düşünmelerine, Yazmaya Yönelik Tutumlarına ve Kalıcılığa Etkisi*
}

\author{
Yasemin UZUN** \\ Merve SÜNTER ${ }^{* * *}$
}

\begin{abstract}
Öz
Bu araştırmanın amacı 6. sınıf Türkçe dersinde süreç temelli hazırlanan tartışmacı metin yazma öğretiminin öğrencilerin eleştirel düşünmelerine, tartışmacı metin yazma becerilerine, yazmaya yönelik tutumlarına ve kalııılığa etkisini araştırmaktır. Bu araştırma, deneysel modele dayalı olarak ön test-son test kontrol gruplu desene göre yapılmıştır. Araştırmanın çalışma grubu, 2015-2016 eğitim öğretim yılında İstanbul ili, Sultangazi ilçesinde İsmetpaşa Ortaokulu' nda öğrenim gören 6/B sınıfına (deney grubuna) devam eden 32 ve 6/D sınıfına (kontrol grubuna) devam eden 32 öğrenci olmak üzere 64 katılımcıdan oluşmaktadır. Araştırma verileri TRÖP (2012) tarafından önerilen Tartışmacı Yazmaya Yönelik Açık Uçlu Soru/ Kompozisyon Konusu, Tiryaki (2011) tarafından geliştirilen Tartışmacı Metin Elementleri Dereceli Puanlama Anahtarı, P.A Facione, tarafından geliştirilen, Kökdemir (2003) tarafından Türkçe' ye uyarlanan California Eleştirel Düşünme Eğilimi Ölçeği (The California Critical Thinking Disposition Inventory / CCTDI), Bacanlı (1997) tarafından geliştirilen ve araştırmanın amaçları doğrultusunda bazı maddelerin düzenlenmesi ve eklenmesi ile 25 maddeden oluşan Kişisel Bilgiler Formu, ve Uygun (2012) tarafından geliştirilen Yazmaya Yönelik Tutum Ölçeği ile toplanmıştır. Ayrıca okuduğunu anlama becerileri araştırmacı tarafından hazırlanan Okuduğunu Anlama Testi ile elde edilmiştir. Araştırmanın sonunda, süreç temelli eleştirel düşünmeye dayalı tartışmacı metin yazma öğretiminin ürün temelli tartışmacı metin yazma öğretimine kıyasla tartışmacı metin yazma becerilerinin ve eleştirel düşünme becerilerinin gelişimi üzerinde daha etkili olduğu belirlenirken, yazmaya yönelik tutumun gelişimi üzerinde daha etkili olmadığı saptanmıştır. Süreç temelli eleştirel düşünmeye dayalı tartışmacı metin yazma öğretiminin ürün temelli tartışmacı metin yazma öğretimine kıyasla tartışmacı metin yazma becerilerinin kalıcılığı üzerinde daha etkili olduğu belirlenirken, eleştirel düşünme becerisinin kalıcılığı ve yazmaya yönelik tutumun kalıcılı̆̆ı üzerinde daha etkili olmadığı saptanmıştır.

Anahtar Kelimeler: Süreç temelli yazma öğretimi, ürün temelli yazma öğretimi, eleştirel düşünme, tartışmacı metin, yazmaya yönelik tutum, kalııılık.
\end{abstract}

\section{The Effect of Argumentative Writing on Students' Writing Skills, Critical Thinking Skills, Attitudes towards Writing and Retention}

\section{Abstract}

This study aims to investigate the effect of argumentative writing on $6^{\text {th }}$ grade students' critical thinking, argumentative text writing skills, attitudes towards writing and retention in Turkish course. This study was designed as pre-test post-test control group of empirical model. Study group of this study consists of 64 participants (32 students experiment group and 32 students control

\footnotetext{
* Bu makale "Tartışmacı Metin Yazma Öğretiminin Öğrencilerin Yazma Becerilerine, Eleştirel Düşünmelerine, Yazmaya Yönelik Tutumlarına ve Kalıcılığa Etkisi" adlı tezden üretilmiştir.

** Dr.Öğr.Üyesi, Çanakkale Onsekiz Mart Üniversitesi, Eğitim Fakültesi, Türk Dili ve Edebiyatı, Çanakkale, yaseminuzun@hotmail.com, ORCID: 0000-0001-8995-772X

*** Öğretmen, MEB, Şehit Hikmet Baysal Ortaokulu, İstanbul, mervesunter39@hotmail.com, ORCID: 0000-000199720400
} 
group) in İsmetpaşa Elementary School in Sultangazi/ İstanbul in 2015-2016 school year. 53,12 percentage of the participants was female $(n=34)$ and 46,87 percentage of them was male $(n=30)$. The data of this study was collected by Open-Ended Question/Essay Content Aimed at Argumentative Writing which was suggested by Ministry of Education(2012), Grading Key for Argumentative Writing Text Elements which was developed by Tiryaki (2011), The California Critical Thinking Disposition Inventory/CCTDI which was developed by P.A. Facione and translated into Turkish by Kökdemir (2003), Personal Details Form by Bacanlı (1997) which consisted of 25 items and Attitude Scale for Writing by Uygun(2012). Besides, reading comprehension skills were achieved by Reading Comprehension Test which was formed by the researcher. At the end of the study, process based argumentative text writing was determined to be more effective on the development of argumentative text writing skills and critical thinking skills when compared to product-based teaching, and determined not to be more effective on the development of attitudes towards writing. While process based argumentative text writing depended on critical thinking was determined to be more effective on retention of argumentative text writing skills when compared to product-based teaching argumentative text writing, and determined not to be more effective on retention of critical thinking skills and attitudes towards writing.

Keywords: Teaching process based writing, teaching product based writing, critical thinking, argumentative text, attitude towards writing, retention.

\section{Giriş}

Yazma öğretimi alanında "süreç temelli yazma modeli" eğitim öğretim hayatında yapılandırmacı yaklaşım ile birlikte kullanılmaya başlanmıştır. "Bu yaklaşım, yazıyı yazmadan önce ve yazım esnasında ortaya çıkan farkı süreçlerle, alt beceriler üstünde durur ve stratejiler üretir. Bu alt süreçler, ön yazım, taslak yazma, gözden geçirip düzeltme, redaksiyon ve yazım işlemi bitene kadar uyumun korunmasını kapsar" (Oral, 2003: 25). Süreç temelli yazma modelinin eğitim öğretim sürecine geçirilememesi öğretim programları ile öğretim sürecinin kopuk olmasına ve öğretim hedeflerinin gerçekleştirilememesine sebep olmaktadır. Yazma öğretiminde ürün temelli yazma modelinin kullanılması, öğrenciler ile yazma becerileri arasında da bir kopukluk oluşmasına ve öğrencilerin yazmaya yönelik olumsuz tutumlar geliştirmesine neden olmaktadır. Yaklaşımın öğrenciler açsından oluşturduğu olumsuzları Ülper (2008: 40) şu şekilde ifade etmiştir: "Yazma edimi öğretmenlerin sonrasında değerlendirmek için verdikleri ev ödevlerinin zorunlu bir gereği olarak gerçekleştirilir. Yazma ediminin gerçekleştiği bu tür öğretim ortamları öğrencilerde kaygı oluşturur."..

Süreç temelli yazma yaklaşımı; yazılan metnin son halinin öğretmen tarafından değerlendirilmesi aşamasına odaklanan ve önemli olanın yazılan yazı olduğunu kabul eden ürün temelli yaklaşımdan farklı olarak yazının son haline odaklanmak yerine yazma sürecinin aşamalarına odaklanan, önemli olanın yazma aşamalarının olduğunu kabul eden yazma yaklaşımıdır. (Oral, 2003: 25)

Öte yandan Türkçe Dersi Öğretim Programı́nda Türkçe öğretimi; düşünme, anlama, sıralama, sınıflama, sorgulama, ilişki kurma, eleştirme, tahmin etme, analiz-sentez yapma, değerlendirme gibi zihinsel becerilerin geliştirilmesi amaçlanmıştır (TRÖP, 2015: 5). Hatta düşünme, anlama, sıralama, sınıflama, sorgulama, ilişki kurma, eleştirme, tahmin etme, analiz-sentez yapma ve değerlendirme gibi zihinsel beceriler ön plana çıkarılmıştır (TRÖP, 2015: 5). Bu sebep ile Türkçe derslerinde yazma öğretimi, yazma alanının temel becerileri yanında üst düzey bilişsel becerileri de geliştirecek şekilde planlanmalıdır. Derslerde uygulanan yazma etkinliklerinde zihinsel becerilerin işe koşulması öğrencilerin derslerde daha aktif olmalarını sağlamakta bu sayede uygulanan yazma çalışmaları öğrencilerin yazma becerileri yanında zihinsel becerilerini ve yazma eylemine yönelik tutumlarını da olumlu yönde etkilemektedir.

Ayrıca Türkçe Dersi Öğretim Programı́nda programın genel amaçlarından biri, “Okuma ve yazma sevgisi ile alışkanlığını kazanmalarını sağlamak" olarak ifade edilmiştir (2015: 6). Türkçe dersi öğretimi ile öğrencilerin hem dil ve zihinsel becerilerinin hem de duyuşsal becerilerinin geliştirilmesi amaçlanmıştır. Bu düşünce temel alındığından dolayı dil becerilerinden yazma becerisi, zihinsel becerilerden eleştirel düşünme becerisinin gelişimi amaçlanan bu araştırmada öğrencilerin duyuşsal 
özellikleri göz ardı edilmemiş ve diğer beceriler ile ilişkili olan öğrencilerin tutumlarının da geliştirilmesi hedeflenmiştir.

Bu araştırmanın genel amacı; altıncı sınıf Türkçe dersinde süreç temelli hazırlanan eleştirel düşünmeye dayalı tartışmacı metin yazma öğretiminin öğrencilerin eleştirel düşünmelerine, tartışmacı metin yazma becerilerine, yazmaya yönelik tutumlarına ve kalıcılığa etkisini araştırmaktır. Bu genel amaç çerçevesinde araştırmanın alt problemleri belirlenmiştir:

a. Süreç temeli hazırlanan eleştirel düşünmeye dayalı yazma öğretimi uygulanan deney grubu ile ürün temeli yazma öğretimi gören kontrol grubunun eleştirel düşünme eğilimi son test puanları arasında anlamlı farklılık var mıdır?

b. Süreç temeli hazırlanan eleştirel düşünmeye dayalı yazma öğretimi uygulanan deney grubu ile ürün temeli yazma öğretimi gören kontrol grubunun eleştirel düşünme eğilimi kalıcılık puanları arasında anlamlı farklılık var mıdır?

c. Süreç temeli hazırlanan eleştirel düşünmeye dayalı yazma öğretimi uygulanan deney grubu ile ürün temeli yazma öğretimi gören kontrol grubunun yazmaya yönelik tutum son test puanları arasında anlamlı farklılık var mıdır?

d. Süreç temeli hazırlanan eleştirel düşünmeye dayalı yazma öğretimi uygulanan deney grubu ile ürün temeli yazma öğretimi gören kontrol grubunun yazmaya yönelik tutum kalıcılık testi puanları arasında anlamlı farklılık var mıdır?

e. Süreç temeli hazırlanan eleştirel düşünmeye dayalı yazma öğretimi uygulanan deney grubu ile ürün temeli yazma öğretimi gören kontrol grubunun tartışmacı metin yazma son test puanları arasında anlamlı farklılık var mıdır?

f. Süreç temeli hazırlanan eleştirel düşünmeye dayalı yazma öğretimi uygulanan deney grubu ile ürün temeli yazma öğretimi gören kontrol grubunun tartışmacı metin yazma kalıcılık testi puanları arasında anlamlı farklılık var mıdır?

\section{Araştırmanın Modeli}

\section{Yöntem}

Altıncı sınıf Türkçe dersinde süreç temelli hazırlanan eleştirel düşünmeye dayalı tartışmacı metin yazma öğretiminin öğrencilerin eleştirel düşünmelerine, tartışmacı metin yazma becerilerine, yazmaya yönelik tutumlarına ve kalıcılığa etkisini araştırmayı amaçlayan bu çalışma, deneysel modele dayalı olarak, ön test-son test kontrol gruplu desene göre yapılmıştır. Deneysel çalışmalar, nedensonuç ilişkilerini belirlemek amacı ile doğrudan araştırmacının kontrolü altında, gözlenmek istenen verilerin üretildiği araştırma modelleridir. Deneme modelli bir araştırmada, amaçlar genellikle denence ya da hipotez şeklinde ifade edilir. Böylece olayların olası nedenlerine yönelik yargılar sınanmış olur (Karasar, 2008).

Araştırmada, ön test veri analizleri sonuçlarına göre birbirine denk iki grup belirlenmiştir. Bu gruplardan biri deney grubu, diğeri kontrol grubu olarak seçkisiz olarak atanmıştır. Araştırma sürecinde her iki gruba da ön test, son test ve kalıcılık testleri uygulanmıştır. Modelde ön testlerin bulunması, grupların deney öncesi benzerlik derecelerinin bilinmesine ve son test sonuçlarının buna göre yorumlanmasına yardımcı olmaktadır (Karasar, 2008).

Uygulanan ön test, son test ve kalıcılık testlerinden alınan puanların araştırmanın denencelerine yönelik olarak Statistical Package for Social Sciences for Personal Computers (SPSS) paket programı kullanılmıştır.

\section{Araştırma Grubu}

Araştırmanın çalışma grubunu, 2015-2016 eğitim-öğretim yılı bahar döneminde, İstanbul ili Sultangazi ilçesinde bulunan İsmetpaşa Ortaokulu'nda öğrenim gören 6. sınıf öğrencileri oluşturmaktadır. Deney ve kontrol grubu, çalışma grubuna dâhil olabilecek altıncı sınıflardan beş şube arasından yapılan ön test veri analizleri sonucunda yansız olarak belirlenmiştir. Ölçme araçları uygulanarak birbirine denk iki grubun 6/B ile 6/D şubeleri oldukları belirlenmiştir. Deney grubu olan 6/B şubesinde 32 öğrenci, kontrol grubu olan 6/D şubesinde ise 32 öğrenci araştırmada yer almıştır. 


\section{Veri Toplama Araçları}

Bu çalışmada, Kişisel Bilgiler Formu, Okuduğunu Anlama Testi, Tartışmacı Metin Dereceli Puanlama Anahtarı, California Eleştirel Düşünme Eğilimi Ölçeği, Yazmaya Yönelik Tutum Ölçeği kullanılmıștır.

Kişisel Bilgiler Formu (KBF)

Uygulanan kişisel bilgiler formu, Bacanlı' nın sosyo-ekonomik düzey (sed) ölçeği örnek alınarak araştırmanın amaçları doğrultusunda bazı maddelerinin çıkarılıp bazı maddelerinin değiştirilmesi ve gerekli görülen maddelerin eklenmesi ile 25 sorudan oluşturulmuştur (1997). Oluşturulan kişisel bilgiler formunda; öğrencilerin beşinci sınıf yıl sonunda aldığı belge, tartışma yöntemini ders dışındaki zamanlarda kullanıp kullanmadıkları, televizyonda veya bilgisayarda tartışma programı izleyip izlemedikleri, ödevler haricinde yazı yazmaya zaman ayırıp ayırmadıkları gibi sorulara yer verilmiştir.

\section{Okuduğunu Anlama Testi}

Okuduğunu anlama becerisi ile ilgili alan yazında var olan araştırmalar ve yayınlar incelenerek uygulanan Okuduğunu Anlama Testi, araştırmacı tarafından geliştirilmiştir. Test yedi metin ve metinlerle ilgili 50 sorudan oluşmaktadır. Sorular, araştırmanın amaçları doğrultusunda hazırlanmıştır. Okuduğunu Anlama Testi' nin geçerlik çalışması için iki alan uzmanın görüşleri alınmıştır. Geliştirilen testlerde güvenirlik katsayı (Cronbach Alfa) testin güvenirliğinin ortaya konulmasında önemli olarak görülmektedir. Okuduğunu anlama testinin güvenirlik katsayısı Cronbach $\alpha=0,91$ olarak hesaplanmıştır. Büyüköztürk (2013) bir testin güvenirlik katsayısının 0,70 ve daha yüksek olması test puanlarının güvenirliği için yeterli olduğunu ifade etmektedir. Bu doğrultuda okuduğunu anlama başarı testinin güvenilir bir test olduğu söylenebilir.

\section{Tartışmacı Metin Dereceli Puanlama Ölçeği}

Uygulama sürecinin etkisini sayısal verilerle kanıtlayabilmek için öğrencilere ön test, son test ve kalııılık testi olarak tartışmacı metin yazdırılmıştır. Yazdırılan tartışmacı metinlerin puanlanması aşamasında Tiryaki tarafından geliştirilen Tartışmacı Metin Dereceli Puanlama Ölçeği kullanılmıştır (2011). Tiryaki, yüksek lisans tezi için geliştirdiği dereceli puanlama ölçeğinin geçerlik ve güvenirlik hesaplamalarını yaparak bu hesaplar sonucunda ölçeğin geçerli ve güvenilir bir ölçek olduğu kanıtlanmıştır (2011).

\section{California Eleştirel Düşünme Eğilimi Ölçeği (CCTDI)}

Uygulanan ölçek, 1990 yılında Amerikan Felsefe Derneği'nin düzenlediği Delphi projesinin bir sonucu olarak ortaya çıkmıştır. Türkçeye uyarlama çalışması Kökdemir (2003) tarafından yapılmıştır. Kökdemir' in çalışması sonucu 75 maddeden oluşan ölçek, 6 boyut ve 51 maddeye indirgenmiştir. Maddelerin 29'u olumlu, 22'i ise olumsuz maddelerden oluşmaktadır. Maddeler 6'lı likert tipinde derecelendirilmiştir. Dereceleme şu şekildedir: 1-Hiç katılmıyorum 2-Katılmıyorum 3-Kısmen katılmıyorum 4-Kısmen katılıyorum 5-Katılıyorum 6-Tamamen katılıyorum (Aybek, 2006, s. 107). Olumlu maddeler 6 puandan 1 puana doğru iken olumsuz maddeler tam tersi şeklinde 1 puandan 6 puana doğru puanlanmıştır. CCTDI' de her bir alt ölçek için puanı $40^{\prime}$ dan düşük olan kişilerin o boyuttaki eleştirel düşünme eğilimlerinin düşük, puanı 50 'den yukarı olanların ise yüksek eleştirel düşünme eğilimine sahip olduklarını söylemektedir (Aybek, 2006, s. 107).

\section{Yazmaya Yönelik Tutum Ölçeği (YYTÖ)}

Çalışmada, 2012 yılında Uygun tarafından doktora tezinde geliştirilen yazmaya yönelik tutum ölçeği kullanılmıştır. Yirmi iki maddeden oluşan tek boyutlu Yazmaya Yönelik Tutum Ölçeği' nin Cronbach Alfa güvenirlik katsayısı 0,95 olup toplam varyansın \%50,45'ini açıklamaktadır. Ölçek, likert tipinde olup olumlu ifadeler için 3-2-1, olumsuz ifadeler için 1-2-3 şeklinde ters puanlanmıştır. Asıl uygulamada kullanılan ölçekte, 14 olumlu ve 8 olumsuz toplam 22 tutum ifadesi yer almaktadır. Ölçekten elde edilebilecek en düşük puan 22 , en yüksek puan ise $66^{\prime}$ dır.

\section{Verilerin Toplanması}


Araştırmanın veri analizlerinde kullanılacak veri toplama araçları üç aşamada öğrencilere uygulanmıştır. Araştırmanın problemlerini sınamak amacıyla gerçekleştirilen süreçte verilerin toplanma aşamaları aşağıda belirtilmiştir:

Illk olarak yansız olarak belirlenecek deney ve kontrol gruplarının seçimi için araştırma sürecinin başında öğrencilere Kişisel Bilgiler Formu, Okuduğunu Anlama Testi, California Eleştirel Düşünme Eğilimi Ölçeği ve Yazmaya Yönelik Tutum Ölçeği uygulanmış, bu veri toplama araçları ile birlikte öğrencilerin uygulamadan önceki tartışmacı metin yazma becerilerini belirlemek amacıyla araştırmacı tarafından verilen tartışmacı metin konusu ile ilgili öğrencilere tartışmacı metin yazdırılmış, yazılan tartışmacı metinler Tartışmacı Metin Dereceli Puanlama Anahtarı ile puanlanmıştır. Veri toplama araçları ile elde edilen ölçümlerin veri analizleri için gerekli işlemler yapılmış ve birbirine denk iki grup, 32 kişilik 6/B şubesi deney grubu ve 32 kişilik 6/D kontrol grubu yansız olarak belirlenmiştir.

íkinci aşamada ise, deney grubunda araştırmacı tarafından eleştirel düşünmeye dayalı tartışmacı metin yazma öğretimi, gerekli materyaller kullanılarak dört hafta süreyle işlendikten sonra, aynı süreçte kontrol grubunda ise geleneksel öğretim yöntemi ile tartışmacı metin yazma öğretimi işlendikten sonra öğrencilerin uygulama süreci sonunda yazma ile eleştirel düşünme becerilerindeki ve yazmaya yönelik tutumlarındaki değişimleri görmek amacıyla California Eleştirel Düşünme Eğilimi Ölçeği ve Yazmaya Yönelik Tutum Ölçeği son test olarak uygulanmıştır. Ayrıca ön testte yazılan tartışmacı metin konusu ile aynı tartışma konusu öğrencilere tartışmacı metin son test olarak tekrar yazdırılmıştır.

Üçüncü aşamada ise, son testlerin uygulanmasından iki hafta sonra deney grubu ve kontrol grubuna kalıcılık testi olarak, California Eleştirel Düşünme Eğilimi Ölçeği ve Yazmaya Yönelik Tutum Ölçeği uygulanmış ve ön test ve son test olarak uygulanan tartışmacı metin yazılarında ele aldıkları tartışma metni konusundan farklı bir konu ile ilgili tartışmacı metin, kalıcılık testi olarak tekrar yazdırılmıştır.

Araştırmanın uygulama aşamasında gerçekleştirilen tartışmacı metin yazma öğretiminde deney grubunda süreç temelli yazma öğretim aşamaları temel kabul edilmiştir. Derslerin genel işleniş süreci aşağıdaki gibidir:

Ilk dersten itibaren tartışmacı metin yapısı birimleri (veri, iddia, iddiaya ait destek gerekçesi, karşı iddia, karşı iddia destek gerekçesi, karşı iddia çürütme gerekçesi, sonuç) sırayla ele alınır. Tartışmacı metin birimleri örnek tartışmacı metin üzerinden irdelenir. Derste işlenen birimi, kendilerine verilen aynı konuda birim özelliklerini dikkate alarak kendi tartışma metni birimini yazmaları istenir. Tüm birimlerin öğrenimi bittikten sonra, öğrencilere bir sonraki derste değerlendirilecek olan tartışmacı metin konusu açıklanır. Öğrencilerden bir sonraki derse kadar, çeşitli bilgi kaynaklarından (internet, okul içi ve okul dışı yaşantılarına yönelik gözlemler) ilgili tartışma konusuyla ilgili araştırma yapmaları istenir.

Öğretmen tarafından ele alınacak tartışma konusu ile ilgili alan yazın araştırıldıktan sonra öğrenciler için gerekli kısaltmalar yapılarak çoğaltılan konu ile ilgili yazılı materyaller öğrencilere dağıtılır.

Öğrenciler kendilerine dağıtılan tartışma konu ile ilgili yazıları analiz ederek kendi araştırmaları sonucunda oluşturdukları iddiaları ile gerekçeleri metinde savunulan görüş ve gerekçeler ile karşılaştırırlar. Tartışma konusunu değerlendirirken düşünemedikleri iddialarına destek gerekçelerinin ve karşı iddialarına çürütme gerekçelerinin farkına varırlar.

Daha sonra öğrencilerin araştırmaları sonucunda savunacaklarına karar verdikleri iddialar sınıf tartışması ile öğretmen tarafından sözlü olarak alınarak sınıf tartışması başlatııı. Böylece öğrenciler kendi iddiaları ile destek gerekçelerini sunar aynı zamanda kendi iddialarını savunan diğer arkadaşlarının destek gerekçeleri ile kendi destek gerekçelerini karşılaştırarak görüşlerini geliştirir. Ayrıca, karşı iddiayı savunan arkadaşlarının destek gerekçelerini dinleyerek karşı görüşü anlar ve nitelikli bir tartışma metni için gerekli ve önemli olan karşı iddianın destek gerekçelerini, çürütme gerekçeleri ile çürütmeye çalışır. Böylece öğrenciler eleştirel düşünme sürecine aktif katılmış olurlar.

Tartışma metni konusu ile ilgili örnek nitelikli tartışma metni, akıllı tahtada açılır ve çoğaltılan aynı metnin fotokopileri öğrencilere dağıtılır. Yeterli sessiz okuma süresi verilir. 
Öğrencilere kendilerinin yazacakları tartışmacı metinler için A4 kâğıtları dağıtılır. Yazma sürecinin hazırlık aşamasındaki basamaklar öğretmen rehberliğinde uygulanır. (Amaç belirleme, hedef kitleyi belirleme, konu ile ilgili düşünceleri ortaya koyma.) Tartışma metninin birimleri, soru cevap tekniği kullanılarak öğrencilerin bu birimlerin özelliklerini hatırlamaları sağlanır. Illk birimden itibaren birim özellikleri hatırlandıktan sonra her birim sıra ile yazılır.

Tartışma metni konusu ile örnek metinden de yararlanarak tüm öğrenciler kendi tartışmacı metinlerinin ilk birimi olan "veri" birimini yazarlar.

Yazdıkları birimi; birim özelliklerine uygunluk, içerik (başlık, kullandıkları kelimeler, paragrafın bütünlüğü, paragrafın akıcılığı, kullandıkları üslup) ve biçim yönünden (oluşturdukları sayfa düzeni, yazım ve noktalamaları, okunaklıık) değerlendirdikten sonra sınıfa sesli okurlar.

Öğretmen yanlış, eksik, ya da doğru olan ifadeler ile ilgili dönütü hemen o esnada öğrencilere açıklar.

Öğrencilerin sınıfa sesli okuduğu tartışmacı metin birimi ile ilgili doğru kısımlar da öğretmen tarafından ifade edilerek öğrencilerin yazmaya yönelik güdüleri arttırılmaya çalışılır ayrıca bu sayede öğrencilerin yazmaya karşı olumlu tutum geliştirmeleri sağlanmaya çalışılır.

Öz değerlendirme amacıyla öğrencilere öğretmen tarafından ön testlerin değerlendirmesinde kullanılan ve son test ve kalıcılık testinin değerlendirmesinde de kullanacağı Tartışma Metni Dereceli Puanlama Anahtarı dağıtılır. Anahtarın kullanımı ile ilgili gerekli açıklamalar öğretmen tarafından yapılır. Ardından her öğrenci kendi yazdığı tartışmacı metnin ilk birimini Tartışma Metni Dereceli Puanlama Anahtarı ile karşılaştırarak uygun puanı metin birimine verir. Böylece öğrencilere kendilerinin yazdıkları metinleri eleştirel biçimde değerlendirebilme becerisi kazandırılmaya çalışıır ayrıca bu yöntemle tartışmacı metnin özelliklerini tekrar değerlendirmeleri sağlanır.

Illk birim tamamlandıktan sonra tüm tartışma metni birimleri tamamlanana kadar her birim için uygulanan süreç temelli yazma süreci devam ettirilir.

Tartışma metnini tamamlayan öğrencilerden gönüllü olanlar tahtaya kaldırılarak yazdıkları tartışmacı metinleri dinlenir.

Yazılan tartışmacı metinler sınıfla paylaşıldıktan sonra bir sonraki tartışma metin konusu öğrencilere açıklanır. Uygulanan süreç temelli yazma aşamaları dönüşümlü bir şekilde devam eder.

Ders sonunda öğrencilerin yazdıkları tartışmacı metin birimleri öğretmen tarafından bir sonraki derste öğrencilere geri verilmek üzere toplanır, yazılar biçim ve içerik açısından tekrar değerlendirilir, yazıların eksik, yanlış ya da doğru kısımları metin üzerinde kısa açıklama ve yönergeler eklenerek belirtilir. Tartışma Metni Dereceli Puanlama Anahtarı kullanılarak puanlama bir kez de öğretmen tarafından yapılır. Öğrencilerin kendi kâğıtlarını kendilerinin değerlendirmelerinde hata olup olmadığı da sınanır.

\section{Verilerin Analizi}

Deney ve kontrol grubundaki katılımcılardan elde edilen ön test, son test ve kalıcılık testi verileri Statistical Package for Social Sciences for Personal Computers (SPSS) paket programına aktarılarak grupların ön test, son test ve kalıcılık testlerinden aldıkları puanlar arasında anlamlı farklıığın olup olmadığının belirlenmesi için istatistiksel analiz yapılmıştır.

Deney ve kontrol grupları belirlenirken uygulanan testlerin sınıflara göre anlamlı farklılı̆ın olup olmadığı da öncelikle incelenmiştir. Bu açıdan sınıf düzeylerine göre uygulanan testlerde anlamlı farklılığın olup olmadığının belirlenmesinde öncelikle normalliğe bakılmıştır. Normallik analizleri doğrultusunda normal dağılan veri gruplarının sınıflara göre uygulanan testler arasında farklılı̆ın belirlenmesinde ilişkisiz örneklemler için Tek faktörlü Varyans Analizi (ANOVA), normal dağılım göstermeyen veri gruplarının sınıflara göre uygulanan testler arasında farklılığın belirlenmesinde ise Kruskall Wallis $\mathrm{H}$-testi analizinden yararlanılmıştır.

Araştırmanın alt problemleri doğrultusunda deney ve kontrol grubunun karşılaştırılmasında normal dağılan veri grupları için parametrik testlerden olan ilişkisiz örneklemler için t testi analizinden, normal dağılım göstermeyen veri grupları için ise parametrik olmayan analiz yöntemlerinden Mann Whitney $U$ analizinden faydalanılmıştır. 
Tartışmacı Metin Yazmanın Öğrencilerin Yazma Becerilerine, Eleştirel Düşünmelerine, Yazmaya Yönelik Tutumlarına ve Kalıcılığa Etkisi

\section{Bulgular}

Deney ve kontrol grupların California Eleştirel Düşünme Eğilimi Ölçeği son testleri puan ortalamaları arasında anlamlı bir farklılığın olup olmadığını belirlemek için parametrik testlerden ilişkisiz örneklemler için T testi analizi yapılmıştır. Iliş̧kisiz örneklemler için T testi analiz tablosu aşağıda verilmiştir:

Tablo 1.

T Testi Analiz Tablosu

\begin{tabular}{lllllll}
\hline $\begin{array}{l}\text { Eleştirel Düşünme } \\
\text { Eğilimi Son Testi } \\
\text { Gruplar }\end{array}$ & $\mathrm{N}$ & $\mathrm{X}$ & $\mathrm{S}$ & $\mathrm{Sd}$ & $\mathrm{T}$ & $\mathrm{P}$ \\
\hline Deney & 32 & 4,07 &, 45 & 62 & 2,01 & $0,04^{*}$ \\
Kontrol & 32 & 3,86 &, 39 & & & \\
\hline $\mathrm{p}^{*}>0.05$ & & & & & &
\end{tabular}

Iliş̧isiz örneklemler için T testi analiz tablosu incelendiğinde $p$ anlamlılık değerinin $(p=0,04)$ 0,05 'ten küçük olduğu görülmektedir. Dolayısıyla deney ve kontrol gruplarının Eleştirel Düşünme Eğilimi son testleri arasında anlamlı farklıığın olduğu söylenebilir. Bu sonuçtan hareketle elde edilen bu anlamlı farklılı̆ın deney grubu lehine olduğu söylenebilir.

Deney ve kontrol grupların California Eleştirel Düşünme Eğilimi Ölçeği kalıcılık testleri puan ortalamaları arasında anlamlı bir farklılığın olup olmadığını belirlemek için parametrik olmayan testlerden Mann Whitney $U$ testi analizi yapılmıştır. Mann Whitney $U$ testi analiz tablosu aşağıda verilmiştir:

Tablo 2.

Mann Whitney U Testi Analiz Tablosu

\begin{tabular}{llllll}
\hline $\begin{array}{l}\text { Eleştirel Düşünme } \\
\text { Eğilimi Kalıclık } \\
\text { Testi }\end{array}$ & $\mathrm{N}$ & $\begin{array}{l}\text { Sıra } \\
\text { ortalaması }\end{array}$ & $\begin{array}{l}\text { Sıra } \\
\text { toplamı }\end{array}$ & $\mathrm{U}$ & $\mathrm{P}$ \\
\hline $\begin{array}{l}\text { Deney } \\
\text { Kontrol }\end{array}$ & 32 & 35,84 & 1147,00 & 405,00 & $0,15^{*}$ \\
\hline
\end{tabular}

$\mathrm{p}^{*}>0,05$

Mann Whitney U tablosu incelendiğinde $p$ anlamlılık değerinin $(p=0,15, p>0,05) 0,05$ 'ten büyük olduğu görülmektedir.

Deney ve kontrol grupların yazmaya yönelik tutum son testi puan ortalamaları arasında anlamlı bir farklıı̆̆ın olup olmadığını belirlemek için parametrik olmayan testlerden Mann Whitney U testi analizi yapılmıştır. Mann Whitney $U$ testi analiz tablosu aşağıda verilmiştir:

Tablo 3.

Mann Whitney U Testi Analiz Tablosu

\begin{tabular}{llllll}
\hline Grup & N & Sira ortalaması & Sıra toplamı & U & $P$ \\
\hline Deney & 32 & 32,81 & 1050,00 & \multirow{2}{*}{502,00} & $0,89 *$ \\
Kontrol & 32 & 32,19 & 1030,00 & & \\
\hline
\end{tabular}

$p^{*}>0,05$

Mann Whitney U testi çıktısı incelendiğinde $p$ anlamlılık değerinin $(p=0,89) 0,05$ 'ten büyük olduğu görülmektedir. Dolayısıyla deney ve kontrol gruplarının yazmaya yönelik tutum son testlerinin puan ortalamaları arasında anlamlı farklıığın olmadığı söylenebilir. 
Deney ve kontrol grupların yazmaya yönelik tutum kalıclık testi puan ortalamaları arasında anlamlı bir farklıığın olup olmadığını belirlemek için parametrik olmayan testlerden Mann Whitney U testi analizi yapılmıştır. Mann Whitney $U$ testi analiz tablosu aşağıda verilmiştir:

Tablo 4.

Mann Whitney U Testi Analiz Tablosu

\begin{tabular}{llllll}
\hline Grup & $\mathrm{N}$ & Sıra ortalaması & Sıra toplamı & $\mathrm{U}$ & $\mathrm{P}$ \\
\hline Deney & 32 & 30,02 & 960,50 & \multirow{2}{*}{432,50} & $0,27^{*}$ \\
Kontrol & 32 & 34,98 & 1119,50 & & \\
\hline
\end{tabular}

$p^{*}>0,05$

Mann Whitney $U$ testi çıktısı incelendiğinde $p$ anlamlılık değerinin $(p=0,27) 0,05$ 'ten büyük olduğu görülmektedir. Dolayısıyla deney ve kontrol gruplarının yazmaya yönelik tutum kalıcılık testlerinin puan ortalamaları arasında anlamlı farklılığın olmadığı söylenebilir.

Deney ve kontrol grupların tartışmacı metin yazma son testi puan ortalamaları arasında anlamlı bir farkıılığın olup olmadığını belirlemek için parametrik olmayan testlerden Mann Whitney $U$ testi analizi yapılmıştır. Mann Whitney $\mathrm{U}$ testi analiz tablosu aşağıda verilmiştir:

Tablo 5.

Mann Whitney U Testi Analiz Tablosu

\begin{tabular}{llllll}
\hline Grup & $N$ & Sira ortalaması & Sıra toplamı & $U$ & $P$ \\
\hline Deney & 32 & 44,27 & 1416,50 & \multirow{2}{*}{135,50} & $0,00^{*}$ \\
Kontrol & 32 & 20,73 & 663,50 & & \\
\hline$P^{*}<0,05$ & & & & &
\end{tabular}

$p^{*}<0,05$

Mann Whitney $U$ testi çıktısı incelendiğinde $p$ anlamlılık değerinin $(p=0,00) 0,05^{\prime}$ ten küçük olduğu görülmektedir. Dolayısıyla deney ve kontrol gruplarının tartışmacı metin yazma son testlerinin puan ortalamaları arasında anlamlı farklılığın olduğu görülmektedir. Sonuçtan hareketle elde edilen bu anlamlı farklılığın deney grubu lehine olduğu söylenebilir.

Deney ve kontrol grupların tartışmacı metin yazma kalıılık testleri puan ortalamaları arasında anlamlı bir farklıığın olup olmadığını belirlemek için parametrik olmayan testlerden Mann Whitney U testi analizi yapılmıştır. Mann Whitney $U$ testi analiz tablosu aşağıda verilmiştir:

Tablo 6.

Mann Whitney U Testi Analiz Tablosu

\begin{tabular}{llllll}
\hline Grup & N & Sıra ortalaması & Sıra toplamı & $U$ & $P$ \\
\hline Deney & 32 & 45,41 & 1453,00 & 99,00 & $0,00^{*}$ \\
Kontrol & 32 & 19,59 & 627,00 & & \\
\hline
\end{tabular}

$p^{*}<0,05$

Mann Whitney $U$ testi çıktısı incelendiğinde $p$ anlamlılık değerinin $(p=0,00) 0,05$ 'ten küçük olduğu görülmektedir. Dolayısıyla deney ve kontrol gruplarının tartışmacı metin yazma kalıcılık testlerinin puan ortalamaları arasında anlamlı farklılı̆ın olduğu görülmektedir. Sonuçtan hareketle elde edilen bu anlamlı farklılı̆ın deney grubu lehine olduğu söylenebilir.

Tartışma, Sonuç ve Öneriler

Süreç temelli hazırlanan eleştirel düşünmeye dayalı yazma öğretimi uygulanan deney grubu ile ürün temelli yazma öğretimi gören kontrol grubunun California eleştirel düşünme eğilimi son test 
puanları arasında deney grubu lehine anlamlı bir fark görüldüğünden, California eleştirel düşünme eğilimi son test puanları açısından, süreç temelli eleştirel düşünmeye dayalı yazma öğretimi, ürün temelli yazma öğretimine kıyasla öğrencilerin eleştirel düşünme becerilerinin gelişimi üzerinde daha etkili olmuştur.

Süreç temelli hazırlanan eleştirel düşünmeye dayalı yazma öğretimi uygulanan deney grubu ile ürün temelli yazma öğretimi gören kontrol grubunun California eleştirel düşünme eğilimi ölçeği kalıcılık puanları arasında anlamlı fark olmadığından, California eleştirel düşünme eğilimi ölçeği kalıcılık puanları açısından, süreç temelli eleştirel düşünmeye dayalı yazma öğretimi ile ürün temelli yazma öğretimi eleştirel düşünme becerisi üzerindeki etkisi eşittir.

Süreç temelli hazırlanan eleştirel düşünmeye dayalı yazma öğretimi uygulanan deney grubu ile ürün temelli yazma öğretimi gören kontrol grubunun yazmaya yönelik tutum son test puanları arasında anlamlı fark olmadığından, yazmaya yönelik tutum ölçeği son test puanları açısından, süreç temelli eleştirel düşünmeye dayalı yazma öğretimi ile ürün temelli yazma öğretimi yazmaya yönelik tutum üzerinde eşit etkiye sahiptir.

Süreç temelli hazırlanan eleştirel düşünmeye dayalı yazma öğretimi uygulanan deney grubu ile ürün temelli yazma öğretimi gören kontrol grubunun yazmaya yönelik tutum kalıcılık testi puanları arasında anlamlı fark olmadığından, yazmaya yönelik tutum ölçeği kalıcılık testi puanları açısından, süreç temelli eleştirel düşünmeye dayalı yazma öğretimi ile ürün temelli yazma öğretimi yazmaya yönelik tutum üzerinde eşit etkiye sahiptir.

Süreç temelli hazırlanan eleştirel düşünmeye dayalı yazma öğretimi uygulanan deney grubu ile ürün temelli yazma öğretimi gören kontrol grubunun tartışmacı metin yazma son test puanları arasında deney grubu adına anlamlı fark görüldüğünden, son test puanları açısından, süreç temelli eleştirel düşünmeye dayalı yazma öğretimini öğrencilerin tartışmacı metin yazma becerileri üzerinde etkili olmuştur.

Süreç temelli hazırlanan eleştirel düşünmeye dayalı yazma öğretimi uygulanan deney grubu ile ürün temelli yazma öğretimi gören kontrol grubunun tartışmacı metin yazma kalıcılık testi puanları arasında deney grubu adına anlamlı fark görüldüğünden, kalıcılık testi puanları açısından, süreç temelli eleştirel düşünmeye dayalı yazma öğretimini öğrencilerin tartışmacı metin yazma becerileri üzerinde etkili olmuştur.

Deney ve kontrol grubundaki öğrencilerin California Eleştirel Düşünme Ölçeği son test puanları incelendiğinde deney grubunun ortalamalarının kontrol grubundan yüksek olduğu belirlenmiştir. Ulaşılan bulgura göre, süreç temelli eleştirel düşünmeye dayalı öğretimin öğrencilerin eleştirel düşünme becerileri üzerinde ürün temelli tartışmacı metin yazma öğretimine karşı anlamlı farkla daha etkili olduğu kabul edilebilir. Eleştirel düşünme becerisinin de geliştirilmeye çalışıldığı bir yazma öğretiminde, yazma becerisi ile eleştirel düşünme becerisinin birbiri ile ilişkili biçimde artış göstereceği tahmin edilir. Bu çalışma ile elde edilen sonuçlar da bu düşünceyi desteklemiştir.

Deney ve kontrol gruplarındaki öğrencilerin California Eleştirel Düşünme Ölçeği kalıcılık puanları incelendiğinde puanlar arasında anlamlı farkın olmadığı belirlenmiştir. Bu sonuca göre, eleştirel düşünmeye dayalı tartışmacı metin yazma öğretiminin, öğrencilerin eleştirel düşünme becerilerinin kalıcılığı üzerinde ürün temelli tartışmacı metin yazma öğretimine karşı daha etkili olmadığı düşüncesine varılabilir. Bazı üst düzey kazanımları sağlayabileceği düşünülen eğitim kuramlarının uygulamalarında, kazanımların kalıcılığı konusunda geleneksel öğretime kıyasla daha etkili sonuçlar alınamadığı belirlenebilmektedir. Bunu yapılan bazı araştırmalar göstermektedir (Hasırcı ve Türkoğlu, 2005; Coşkun, 1999; Yıldırım, Tarım ve iflazoğlu, 2006; Yazgan, Bintaş ve Altun, 2002'den akt. Berkant, 2007).

Deney ve kontrol gruplarındaki öğrencilerin yazmaya yönelik tutum ölçeği son test puanları incelendiğinde puanlar arası anlamlı bir farkın olmadığı belirlenmiştir. Bu bulgulara göre, süreç temelli eleştirel düşünme becerisine dayalı tartışmacı metin yazma öğretiminin yazmaya yönelik tutum üzerindeki etkisi ürün temelli tartışmacı metin yazma öğretiminin yazmaya yönelik tutum üzerindeki etkisinden farklı olmadığı düşünülebilir. Tutumlar, duyuşsal kazanımlarla ilgilidir. Duyuşsal hedeflerin gerçekleşmesi ise eğitim-öğretimde bilişsel ve zihinsel hedeflere kıyasla daha zor olduğu ve geliştirilmesinin daha uzun süreçte gerçekleştiği kabul edilmektedir. 
Deney ve kontrol gruplarındaki öğrencilerin yazmaya yönelik tutum ölçeği kalıcılık puanları incelendiğinde puanlar arası anlamlı bir farkın olmadığı belirlenmiştir. Bu bulgulara göre, süreç temelli eleştirel düşünme becerisine dayalı tartışmacı metin yazma öğretiminin yazmaya yönelik tutum üzerindeki kalıcılığında, ürün temelli tartışmacı metin yazma öğretiminin yazmaya yönelik tutum üzerindeki kalıcılığından farklı olmadığı düşünülebilir. (Araştırmada son test ile kalıcılık testi iki hafta süre aralığı ile gerçekleştirilmiştir.)

Ayrıca ulaşılan sonuçlara göre duyuşsal özelliklerin değişiminin uzun süre gerektirdiği yargısı bu araştırmanın sonuçları ile desteklenmiştir.

Deney ve kontrol gruplarındaki öğrencilerin tartışmacı metin son test puanları incelendiğinde puanlar arasında deney grubu lehine anlamlı farkın olduğu görülmektedir. Araştırmanın bulguları süreç temelli eleştirel düşünmeye dayalı tartışmacı metin yazma öğretiminin, öğrencilerin tartışmacı metin yazma becerilerini arttırmada daha etkili olduğu hipotezini desteklemektedir. Bu sonuçlardan hareketle süreç temelli eleştirel düşünmeye dayalı tartışmacı metin yazma öğretiminin, öğrencilerin tartışmacı metin yazma becerileri üzerinde ürün temelli tartışmacı metin yazma öğretime kıyasla anlamlı bir fark ile etkili olduğu belirlenmiştir. Deney grubu puanlarının anlamlı bir şekilde yüksek çıkmasında uygulanan yazma öğretiminin süreç temelli olması ve eleştirel düşünme becerisinin ilgili tartışmacı metin yazma öğretiminde kullanılmasının etkili olduğu düşüncesini desteklemektedir. Nitekim yazma öğreniminde süreç temelli bir yaklaşımın esas kabul edilerek uygulanması ve metin türüne ile bağlantılı olan zihinsel becerilerin öğrenciler tarafından geliştirilmesine odaklanan bir yazma öğretiminin, öğrencilerin var olan yazma becerilerini geliştireceği düşünülür. Bu araştırmanın sonuçları da bu düşünceyi desteklemiştir. Ayrıca ürün temelli yürütülen yazma çalışmalarının yeterli olmadığı Ülper (2008) ve Sever (2013) araştırma bulgularıyla örtüşmektedir.

Deney ve kontrol grubundaki öğrencilerin tartışmacı metin kalıcılık testi puanları incelendiğinde, deney grubunun kontrol grubundan daha yüksek olduğu belirlenmiştir. Bu sonuca göre süreç temelli eleştirel düşünmeye dayalı tartışmacı metin yazma öğretiminin, öğrencilerin tartışmacı metin yazma becerilerinin kalıcılığı üzerinde ürün temelli tartışmacı metin yazma öğretimine kıyasla anlamlı derecede daha etkili olduğu kabul edilebilir. Deney grubu öğrencilerinin kalıcılık puanlarının anlamlı derecede yüksek çıkmasında süreç temelli yazma öğretiminin uygulanmasının etkisi olduğu düşünülmektedir. Yazmanın bir süreç olduğunu kabul eden süreç temelli yazma öğretiminin öğrencilerin yazma süreçlerinin aşamalarını kazanmasına odaklanması, öğrencilerin yazma becerilerini geliştirirken aynı zaman da yazma aşamalarındaki kazanımları öğrenen öğrencilerin yazma becerilerindeki başarının artış göstereceği tahmin edilmektedir. Bu nedenle süreç temelli yazma öğretimi ile öğrencilerin yazma becerisinin ürün temelli yazma öğretimine kıyasla daha etkili olduğu bu araştırmanın sonuçları ile desteklenmiştir.

Ayrıca süreç temelli yazma öğretimi, eleştirel düşünmeye dayalı olarak gerçekleştirilirken, ürün temelli yazma öğretiminde öğrencilerin eleştirel düşünme becerilerini geliştirmeye yönelik çalışma yapılmamıştır. Bu sebeple deney grubundaki tartışmacı metin kalıcılık puanlarııın deney grubundan anlamlı derecede yüksek çıkmasının uygulanan yazma öğretiminde eleştirel düşünme becerilerinin de öğretim sürecine katılmış olması olduğu düşünülmektedir. Bu düşüncenin dayanağı ise, araştırmanın tartışmacı metin son testi ile tartışmacı metin kalııılık testi konularının farklı seçilmiş olmasıdır. Araştırmada tartışmacı metin ön testi ile son testinin konusu aynı seçilirken kalıcılık testinin konusu farklı seçilmiştir. Bu seçimin sebebi öğrencilerin tartışmacı metin yapısını ezberleyerek yüksek puan olmalarını engellemektir. Araştırmada tartışmacı metin yazma, yalnızca metin birimlerini bilerek düşünce üretmeden var olan bilgilerini kâğıda geçirmek olarak değil, sunulan her tartışmacı metin konusu ile eleştirel bir düşünme sürecinden sonra düşüncelerini metin birimlerine uygun olarak yazılı hale getirmek olarak kabul edilmiştir. Öğrencilerin nitelikli bir tartışmacı metin yazabilmeleri yazmanın aşamalarını bilmelerinin yanında konuyu eleştirel olarak değerlendirebilmelerine de bağlıdır. Bu sebeple öğrencilerin iki hafta süreden sonra tartışmacı metin puanlarının anlamlı bir şekilde artmasının, uygulanan süreç temelli yazma öğretiminin yanında bu öğretimin öğrencilerin eleştirel becerilerini geliştirecek şekilde gerçekleştirilmesinden kaynaklandığı düşünülmektedir. Öğrenciler, kendilerine sunulan yeni tartışmacı metin konusunu eleştirel bir şekilde düşündükten sonra kendi iddialarını seçip 
destek gerekçelerini sıralayabilmişler ve aynı şekilde karşı iddianın destek gerekçelerini çürütüp bir sonuç ile yazılarını tamamlayabilmişlerdir.

Elde edilen sonuçlar doğrultusunda şu öneriler geliştirilmiştir: Türkçe Dersi Öğretim Programı'na öğretmenlerin tartışmacı metin yazma öğretiminde kullanacakları örnek nitelikli tartışmacı metinler eklenebilir. Öğretmenler yazma aşamalarından hazırlık aşamalarını kullanarak öğrencilerin metin yazma becerilerini geliştirebilirler. Bu araştırmada, okuduğunu anlama becerisi ile tartışmacı metin yazma becerisi arasındaki ilişki yalnız okuduğunu anlama ön testi ile tartışmacı metin ön testlerinin sonuçlarına göre yorumlanmıştır. Farklı bir çalışmada okuma becerisine yönelik hazırlanan ders planlarının uygulanması ile oluşacak okuma becerisi ile tartışmacı metin yazma becerisi arasındaki ilişki belirlenebilir.

\section{Kaynaklar}

Aybek, B. (2006). Konu ve beceri temelli eleştirel düşünme öğretiminin öğretmen adaylarının eleştirel düşünme eğilimi ve düzeyine etkisi. Çukurova Üniversitesi, Adana. YÖK Ulusal Tez Merkezi veri tabanından elde edildi. (205450)

Bacanlı, H.(1997). Eğitim psikolojisi. İstanbul: Kurtiş Matbaacılık.

Berkant, H. (2007). Dokuzuncu sınıf biyoloji dersinde yapıcı öğrenme temelli hazırlanan anlamlı nedensel düşünmeye dayalı öğretimin öğrencilerin anlamlı nedensel düşünmelerine, akademik başarılarına, kalıcılığa ve günlük yaşam davranışlarına etkisi. Çukurova Üniversitesi, Adana. YÖK Ulusal Tez Merkezi veri tabanından elde edildi. (220638)

Büyüköztürk, Ş. (2013). Sosyal bilimler için veri analizi el kitabı. Ankara: Pegem Akademi Yayıncılık. Karasar, N. (2008). Bilimsel araştırma yöntemi. Ankara: Nobel.

Kökdemir, D. (2003). Belirsizlik durumlarında karar verme ve problem çözme (Doktora tezi). Ankara Üniversitesi Sosyal Bilimler Enstitüsü, Ankara.

MEB. (2015). Türkçe dersi öğretim programı (1-8. sınıflar), Ankara: MEB.

MEB. (2018). Türkçe dersi öğretim programı (ilkokul ve Ortaokul 1, 2, 3, 4, 5, 6, 7 ve 8. Sınıflar). Ankara: MEB Yayınları.

Oral, G. (2003). Yine yazı yazıyoruz. (2. Baskı). Ankara: Pegem Akademik.

Sever, E. (2013). Süreç temelli yazma modellerinin ilkokul dördüncü sınıf öğrencilerinin yazılı anlatım ve yaratıcı yazma becerilerine etkisi. YÖK Ulusal Tez Merkezi veri tabanından elde edildi. (Tez no: 361909)

Uygun, M. (2012). Öz düzenleme stratejisi gelişimi öğretiminin yazılı anlatıma, yazmaya yönelik öz düzenleme stratejisine, kalıcılığa ve tutuma etkisi. Hacettepe Üniversitesi, Ankara. YÖK Ulusal Tez Merkezi veri tabanından elde edildi. (317793).

Tiryaki, N. E. (2011). Üniversite öğrencilerinin tartışmacı metin yazma becerileri ile yazma kaygısı ve eleştirel düşünme becerileri. Yayımlanmamış yüksek lisans tezi. Mustafa Kemal Üniversitesi, Hatay. YÖK Ulusal Tez Merkezi veri tabanından elde edildi. ( 279979) .

Ülper, H. (2008). Bilişsel süreç modeline göre hazırlanan yazma öğretim programının öğrenci başarısına etkisi. (Yayımlanmamış doktora tezi). Ankara Üniversitesi, Ankara.

\section{Extended Abstract Introduction}

The process-based writing model, which is accepted as the basis in the field of writing, could not be applied to education as desired. This model focuses on sub-skills and produces strategies through different processes that occur before and during writing. These sub-processes include prewriting, draft writing, review and correction, proofreading. Not being able to apply process-based writing model to education leads to a disruption of the teaching process with the teaching programs and to failure in terms of course objectives. The use of a product-based writing model in teaching of writing leads to a gap between students and writing skills and to negative attitudes towards writing.

Process based writing approach, unlike the product-based approach, which focuses on the evaluation of the final text by the teacher and accepts that writing is important, focuses on the stages of the writing process rather than focusing on the final writing. This approach emphasizes sub-skills 
and developing strategies through different processes that occur before and during writing. These subprocesses include pre-writing, drafting, reviewing and editing, proofreading and preserving compliance until the end of writing process.

Moreover, it aims to develop mental skills such as thinking, understanding, and sorting, classifying, questioning, establishing relationship, criticizing, predicting, analysing-synthesizing and evaluating in the Turkish curriculum (TRÖP, 2015: 5). In fact, mental skills such as thinking, understanding, and sorting, classifying, questioning, relationship building, criticizing, predicting, analysing-synthesizing and evaluating are highlighted (TRÖP, 2015: 5). Because of this reason, teaching writing should be planned in a way to develop basic cognitive skills as well as basic skills of writing. In the writing activities applied in the lessons, mental skills enables the students to be more active in the lessons, so activities affect students' mental skills and attitudes towards writing positively.

In addition, one of the general objectives of the Turkish curriculum is to enable students to acquire the habit of reading and writing. Turkish curriculum should improve not only students' language and mental skills, but also their affective skills.

The aim of this study is to investigate the effect of process based argumentative writing in Turkish course on $6^{\text {th }}$ grade students' critical thinking, argumentative text writing skills, attitudes towards writing and retention.

\section{Method}

This study was designed as pre-test post-test control group of empirical model. Study group of this study consisted of 64 participants (32 students experiment group and 32 students control group) in İsmetpaşa Elementary School in Sultangazi/ İstanbul in 2015-2016 school year. 53,12 percentage of the participants was female $(n=34)$ and 46,87 percentage of them was male $(n=30)$. The data of this study was collected by Open-Ended Question/Essay Content Aimed at Argumentative Writing which was suggested by Ministry of Education(2012), Grading Key for Argumentative Writing Text Elements which was developed by Tiryaki (2011), The California Critical Thinking Disposition Inventory/CCTDI which was developed by P.A. Facione and translated into Turkish by Kökdemir (2003), Personal Details Form by Bacanlı (1997) which consisted of 25 items and Attitude Scale for Writing by Uygun(2012). Besides, reading comprehension skills were achieved by Reading Comprehension Test which was formed by the researcher. Kolmogrov - Simirnov Test was used to identify whether data group distributed normally or not. The normality of data primarily was examined in identifying meaningful difference between experiment group's post-test and post-test retention tests. T test analysis (Paired Sample $t$ test) was used for related samples for data groups displaying normal distribution and Wilcoxon signed test was used to present meaningful difference for data groups which was not displaying normal distribution.

\section{Result and Discussion}

At the end of the study, while the effectiveness of process based argumentative text writing depended on critical thinking on students' argumentative text writing skills and critical thinking skills were determined well, it was not effective on attitudes towards writing. While the process based argumentative text writing depended on critical thinking compared to product-based teaching argumentative text writing was determined to be more effective on the development of argumentative text writing skills and critical thinking skills, it was determined not to be more effective for the development of attitudes towards writing. While the process based teaching argumentative text writing depended on critical thinking compared to product-based teaching argumentative text writing was determined to be more effective on retention of argumentative text writing skills, it was identified that it was not more effective on retention of critical thinking skills and attitudes towards writing. 